Rev. Int. Contam. Ambie. 35 (4) 797-805, 2019

DOI: 10.20937/RICA.2019.35.04.02

\title{
HAZARDOUS POLLUTANTS IN POTABLE GROUNDWATER SOURCES OF PUBLIC SCHOOLS, SOUTHERN PUNJAB (PAKISTAN)
}

Contaminantes peligrosos en fuentes subtarráneas de agua de escuelas públicas, Punjab del sur (Pakistán)

\author{
Muhammad SARFRAZ ${ }^{1}$, Nargis SULTANA ${ }^{2}$ and Muhammad Ilyas TARIQ ${ }^{2}$
}

${ }^{1}$ Pakistan Council of Research in Water Resources (PCRWR), Ministry of Science and Technology, Sargodha, 40100, Pakistan.

${ }^{2}$ Department of Chemistry, University of Sargodha, Sargodha, 40100, Pakistan.

*Corresponding author: sarfrazzed@gmail.com

(Received: July 2018; accepted: January 2019)

Key words: contamination, water quality, health risk assessment, trace metals, chronic daily intake

\begin{abstract}
Drinking water quality is considered to be of vital importance for all human beings and animals but its significance is much more heightened when consumer is a teenager. In view of foregone, groundwater quality assessment of 150 public schools situated in flooded areas of Southern Punjab, Pakistan, was carried out. Analysis results revealed that 49 and $37 \%$ water samples are contaminated with coliform and faecal coliforms, respectively. On the other hand chemicals constituents in samples, including calcium $(43 \%)$, magnesium (11\%), potassium (37\%), sodium $(31 \%)$, sulphate $(39 \%)$, hardness $(31 \%)$, total dissolved solids (TDS) (35\%) and chloride (15\%) were higher than World Health Organization (WHO) limits. The situation is more serious as fluoride, iron and arsenic were also found in high concentration in 15, 60 and $58 \%$ samples, respectively. Health risk assessment data indicated that mean chronic daily intake (CDI) values for children and adults were 0.592 and $0.537 \mu \mathrm{g} / \mathrm{kg} / \mathrm{day}$ for arsenic and 0.012 and $0.011 \mu \mathrm{g} / \mathrm{kg} / \mathrm{day}$ for iron, respectively. Calculated arsenic health risk index (HRI) $>1$ for 88 and $58 \%$ water samples for children and adults respectively, which highlights possible health risks associated with intake of contaminated water.
\end{abstract}

Palabras clave: contaminación, calidad del agua, evaluación de riesgo a la salud, metales traza, ingesta diaria crónica

\section{RESUMEN}

La calidad del agua potable se considera de vital importancia para todos los seres humanos y animales, pero su importancia aumenta mucho más cuando el consumidor es un adolescente. En vista de lo anterior, se llevó a cabo una evaluación de la calidad de las aguas subterráneas de 150 escuelas públicas ubicadas en áreas inundadas del sur de Punjab, Pakistán. Los resultados del análisis revelaron que 49 y $37 \%$ de las muestras de agua están contaminadas con coliformes y coliformes fecales, respectivamente. Por otro lado, los componentes químicos en las muestras que incluyen calcio (43\%), magnesio (11\%), potasio (37\%), sodio (31\%), sulfato (39\%), dureza (31\%), sólidos disueltos totales (TDS) (35\%) y cloruro (15\%)en 43, 11, 37, 31, 39, 31, 35 y $15 \%$ de las muestras fueron mayores que los límites de la Organización Mundial de la Salud (OMS). La situación es más ya que el fluoruro, el hierro y el arsénico también se encon- 
traron en altas concentraciones en 15, 60 y 58\% de las muestras, respectivamente. Los datos de evaluación de riesgo para la salud indicaron que los valores medios de ingesta crónica diaria (CDI, por sus siglas en inglés) para niños y adultos fueron de 0.592 y $0.537 \mu \mathrm{g} / \mathrm{kg} /$ día para arsénico y 0.012 y $0.011 \mu \mathrm{g} / \mathrm{kg} /$ día para el hierro, respectivamente. El índice de rieso, calculado para el arsénico, (HRI, por sus siglas en inglés) fue $>1$ para 88 y $58 \%$ de muestras de agua para niños y adultos, respectivamente, lo que destaca los posibles riesgos para la salud asociados con la ingesta de agua contaminada.

\section{INTRODUCTION}

One third of world's population have no other option than groundwater for their drinking use (Nickson et al. 2005) whereas in Pakistan about $70 \%$ people rely on groundwater for their household use (Malik et al. 2010). Various types of materials on seepage routes, general human activities including use of fertilizers and pesticides, natural disasters, the dissolved solids and domestic and industrial wastes disposal system adversely affect groundwater quality (Phiri et al. 2005). It has been reported that severe contamination of drinking water with various hazardous pollutants and microorganisms was resulted due to floods in different areas of Pakistan, which caused waterborne diseases like diarrhoea, cholera, typhoid fever, food poisoning, dysentery, gastroenteritis, and other serious infections (Baig et al. 2012, Muhammad et al. 2013).

Literally, drinking water must not have any objectionable aesthetic parameter and should be free from organic and inorganic material and pathogens exerting adverse physiological effects on human health (Qadeer 2004). Literature shows that infectious diarrhoea caused by poor sanitation, hygiene and water quality, resulted in 2.2 million deaths per year around the world (WHO 2000). Furthermore, $90 \%$ of these deaths were in children and unfortunately all cases were reported in developing countries (Ashbolt 2004). Waterborne diseases such as dysentery, diarrhoea, tooth decay, anemia and hepatitis in children contribute nearly $80 \%$ of total existing diseases (Memon et al. 2011) and the situation is much more deteriorated in emergencies like floods. In Pakistan, over $40 \%$ deaths in urban areas are attributed to the diseases caused by consumption of water drawn from polluted sources. An investigation conducted in three districts (Badin, Thar and Thatta) of southern Sindh, Pakistan, revealed that consumption of polluted drinking water was the main cause of diseases like diarrhoea, gastroenteritis, dysentery, kidney problems, etc. (Memon et al. 2011).

From a physical and chemical point of view, although the major ions in drinking water are essential nutrients for humans, beyond certain limit these pose serious health hazards. It was observed that high level of total dissolved solids (TDS), fluoride, nitrate, calcium, and total hardness is associated with frequent prevalence of renal gravels and renal stones (Mohamed et al. 2015). Through a number of studies, it has been established that concentrations of different minerals, chemicals and substances in drinking water exceed the World Health Organization (WHO) guideline values (GVs), as found in Cambodia, Zimbabwe, Ghana, Pakistan and Bangladesh (WHO 2004, Wakida et al. 2005, Laluraj et al. 2006, WHO 2010, Memon et al. 2011).

Trace elements if ingested in excess can cause serious health implications. Therefore, it is of vital importance to estimate potential health impact by calculating health risk associated with various contaminants in aquatic ecosystems. Evaluation of heavy metal concentration and health risk assessment have been carried out in various studies which reveal that overall excess concentration of all these metals is toxic (Adepoju-Bello et al. 2005, Venkatramanan et al. 2015). In order to evaluate physical, chemical and microbiological quality of drinking water and estimate associated health risks, a large number of other investigations have also been conducted revealing contamination of most of the water samples analyzed either with chemical and/or microbiological contaminants (Khan et al. 2001, Imitiaz, et al. 2004, Akhter et al. 2010, Mohsin et al. 2013, Shakoor et al. 2015, Rasool et al. 2016, Alamgir et al. 2016).

In continuation of our previous studies (Sarfraz et al. 2016, Sarfraz et al., 2018a, 2018b), we have designed the present project to evaluate microbiological, physical and chemical quality of drinking water sources available in public schools of Southern Punjab, Pakistan.

\section{MATERIALS AND METHODS}

Dera Ghazi Khan and Rajanpur districts are located in between the Koh-Suleman range of 
mountains and the river Indus at $30^{\circ} 3^{\prime} 22^{\prime \prime} \mathrm{N}$ to $70^{\circ}$ $38^{\prime \prime} 04^{\prime \prime} \mathrm{E}$ and $29^{\circ} 6^{\prime \prime} 12^{\prime \prime} \mathrm{N}$ to $70^{\circ} 19^{\prime \prime} 30^{\prime \prime} \mathrm{E}$ respectively, whereas Muzaffargarh district is located in between DG Khan and Multan districts at $30^{\circ} 4^{\prime} 13^{\prime \prime} \mathrm{N}$ to $71^{\circ} 11^{\prime} 36^{\prime \prime}$ E. Water samples from 150 hand pumps situated in public schools of flood affected rural areas of Muzaffargarh, DG Khan and Rajanur districts (Fig.1) were collected for water quality assessment. From each sampling site, three water samples have been collected carefully in clean polypropylene bottles $(600 \mathrm{~mL})$ for evaluation of physical, chemical, trace metals and aesthetic parameters. In addition, sterilized glass bottles $(250 \mathrm{~mL})$ were used for collection of water samples for microbiological analysis, which were stored in ice boxes and immediately shifted to the laboratory.

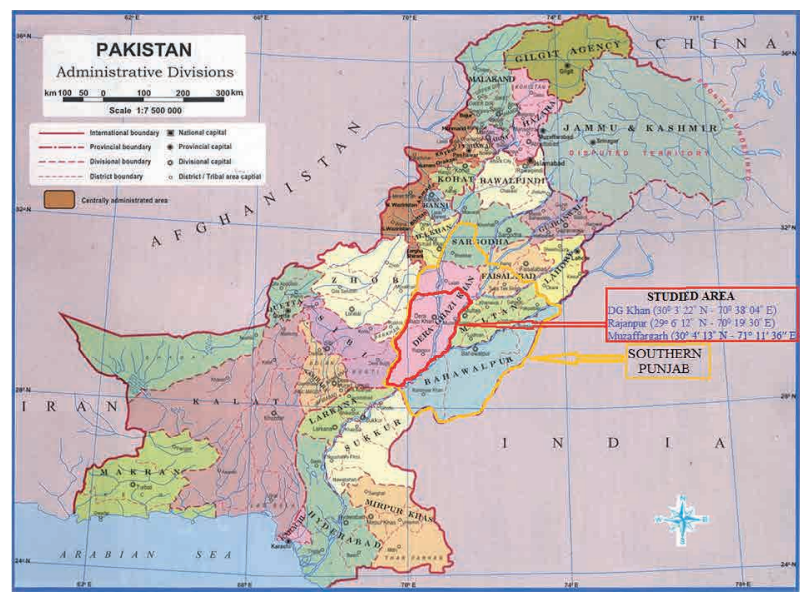

Fig. 1. Graphical presentation of studied area

Analytical grade reagent and chemicals were made available and all instruments used were calibrated prior to analysis of water samples collected. Few water quality parameters such as taste, color, electrical conductivity (EC) and turbidity were estimated by using field testing kits. Membrane filtration technique was used for analysis of microbiological parameters like coliform and faecal coliform (Clesceri et al.2005). Detailed evaluation of other chemical indicators including alkalinity, hardness, sodium $\left(\mathrm{Na}^{+}\right)$, calcium $\left(\mathrm{Ca}^{+2}\right)$, magnesium $\left(\mathrm{Mg}^{+2}\right)$, iron $(\mathrm{Fe})$, potassium $\left(\mathrm{K}^{+}\right)$, sulphate $\left(\mathrm{SO}_{4}{ }^{2-}\right)$, chloride $\left(\mathrm{Cl}^{-}\right)$, fluoride $\left(\mathrm{F}^{-}\right)$, nitrate $\left(\mathrm{NO}_{3}{ }^{-}\right)$, TDS and arsenic (As) have been carried out in a water quality laboratory by using the American Public Health Association (APHA) standard methods (Clesceri et al. 2005).
In short, total coliform and faecal coliform were determined by using M-Endo Agar and M-FC Agar media, respectively. Plates were incubated at $35^{\circ} \mathrm{C}$ and $44.5+0.2^{\circ} \mathrm{C}$ for 24 hours. Appearance of pink to dark red color with metallic surface sheen colonies for total coliform and blue colored colonies for faecal coliform bacteria as CFU/100 mL were calculated. Alkalinity including carbonates and bicarbonates were determined by titration with hydrochloric acid using phenolphthalein and methyl orange as indicators. Calcium and hardness assessment was made by volumetric titration with ethylenediaminetetracetic acid using murioxide and eriochrome black $\mathrm{T}$ as indicator, respectively. The concentration of $\mathrm{NO}_{3}, \mathrm{SO}_{4}$ and $\mathrm{Fe}$ was determined by using spectrophotometric method with barium chloride and $\mathrm{HCl}$ as reagents. Fluoride was estimated by colorimetric method using spadns solution whereas, $\mathrm{Cl}^{-}$was quantified by argentometric titration with $\mathrm{AgNO}_{3}$ using potassium chromate as an indicator. Atomic absorption spectrophotometer (AAS) was used for determination of As using air-acetylene flame for combustion with single-element hollow cathode lamp. Estimation of $\mathrm{Na}$ and $\mathrm{K}$ was carried out by using flame photometer. Finally, TDS was calculated by addition of cations and anions (Clesceri et al. 2005). Other instruments and methods used for current study includes Louibond $\mathrm{PC}_{\mathrm{H}} 63739$ Germany turbidity meter, EC meter of Hannna HI 99300 (Italy), pH meter of Jenway 350, flame photometer (Italy), colorimeter Hach DR 2800, Optizen 2120 UV plus spectrophotometer (Korea).

Chronic daily intake (CDI) and health risk assessment (HRI) for As and $\mathrm{Fe}$ was calculated by using equations 1and 2 (Shah et al. 2012, Muhammad et al. 2010):

$$
C D I=\frac{L w \times M c}{W b}, \quad H R I=\frac{C D I}{R f D} \times 0.001
$$

where $\mathrm{Mc}(\mu \mathrm{g} / \mathrm{L})$ represents the concentration of metal in water and Lw (L/day) presents amount of water consumed daily that may be considered as $1 \mathrm{~L} /$ day for child and $2 \mathrm{~L}$ /day for adults, whereas $\mathrm{Wb}(\mathrm{kg})$ is body weight of respective consumer that can be assumed as $32.7 \mathrm{~kg}$ and $72 \mathrm{~kg}$ for child and adult respectively (Khan et al. 2010). RfD shows the reference dose of trace metals for oral toxicity which is 0.0003 and $0.7 \mathrm{mg} / \mathrm{kg} /$ day for As and Fe respectively and 0.001 is the multiplication factor for converting the RfD from mg to $\mu \mathrm{g}$. Water samples having measured $\mathrm{HRI}<1$ will be considered as safe for consumption. 


\section{RESULTS AND DISCUSSION}

Analysis of aesthetic and physical parameters such as color, taste, odor and turbidity showed that $25 \%$ water samples have saline taste which may be attributed to excess of chemicals. Analysis data of major water quality parameters as range and average values is presented in table I. Microbiological analysis data revealed that $49 \%$ water samples were contaminated with total coliforms bacteria whereas $37 \%$ were found to have faecal coliforms (Fig. 2) which may be attributed to pathogens associated with agricultural waste and human excreta. As per WHO standard, each type of coliform organisms should be absent in water intended to be used for drinking purpose (WHO 1963). Nabeela et al. 2014 showed that drinking water samples contaminated with microbial organisms (total coliforms and faecal coliforms) pose serious impact on public health in Pakistan (Nabeela et al. 2014). Natural disasters like floods and earthquakes are considered among the main water pollution sources due to which human and animal wastes as well as industrial contaminants are liable to enter the main water body through surface water sources and unprotected bore holes (Baig et al. 2012).

$\mathrm{pH}$ measurement indicates acidic or alkaline nature of water. If $\mathrm{pH}$ value is less than 7 , water is considered as acidic whereas $\mathrm{pH}$ above 7 shows alkaline nature of water. $\mathrm{pH}$ controls measured chemical

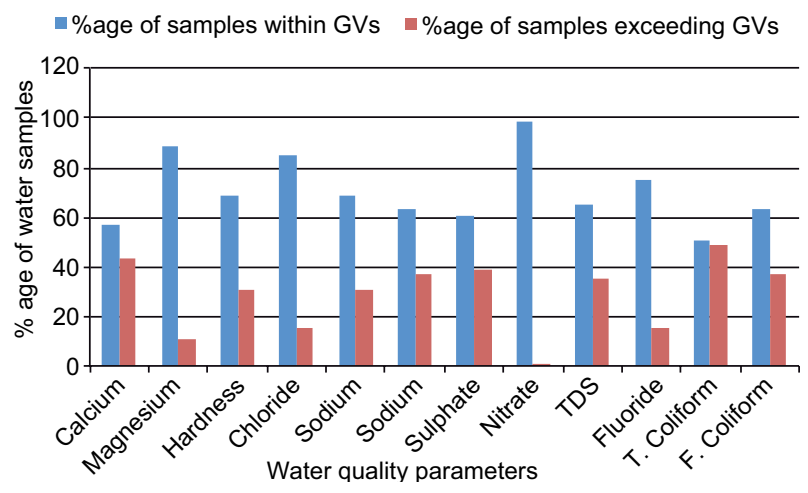

Fig. 2. Comparison of studied water parameters (\%age) with $\mathrm{GV}$

parameters and affects corrosion process in water (Imitiaz et al. 2004). The present study shows that $\mathrm{pH}$ varied from 7.0 to 8.38 as compared to WHO permissible limits (6.5-8.5) (Rice et al. 2012). EC is an indicator of ionic concentration and dissolved solids in a water sample. EC of water samples in the present study varied from as low as $324 \mu \mathrm{S} / \mathrm{cm}$ to as high as $16890 \mu \mathrm{S} / \mathrm{cm}$. Calcium and $\mathrm{Mg}$ are among essential micronutrients but causes hardness of water, resulting digestive system problems and clothes cleaning issues if their concentration is higher than the permissible limit (Khan et al. 1999). Present analysis data (Fig.2) showed that 43, 11 and $31 \%$ water

TABLE I. DISTRICT WISE RANGE AND AVERAGE VALUES OF STUDIED PARAMETERS

\begin{tabular}{|c|c|c|c|c|c|c|c|c|c|}
\hline \multicolumn{2}{|l|}{ District } & \multicolumn{2}{|c|}{$\begin{array}{l}\text { Overall } \\
(\mathrm{n}=150)\end{array}$} & \multicolumn{2}{|c|}{$\begin{array}{l}\text { Muzafargarh } \\
\quad(\mathrm{n}=50)\end{array}$} & \multicolumn{2}{|c|}{$\begin{array}{l}\text { Dera Ghazi Khan } \\
\qquad(\mathrm{n}=50)\end{array}$} & \multicolumn{2}{|c|}{$\begin{array}{l}\text { Rajinpur } \\
(\mathrm{n}=50)\end{array}$} \\
\hline Parameter & GV & Range & Average & Range & Average & Range & Average & Range & Average \\
\hline $\mathrm{Ec}(\mu \mathrm{S} / \mathrm{cm})$ & NGVS & $263-16890$ & 2218 & $324-9055$ & 1410 & $263-6686$ & 1520 & $331-16890$ & 3723 \\
\hline Hard $(\mathrm{mg} / \mathrm{L})$ & $<500$ & $60-4300$ & 613 & $100-1650$ & 305 & $100-2500$ & 528 & $60-4300$ & 60 \\
\hline $\mathrm{Cl}(\mathrm{mg} / \mathrm{L})$ & $<250$ & $14-3010$ & 235 & $14-1680$ & 126 & $17-367$ & 85 & $21-3010$ & 495 \\
\hline Alk (mg/L) & NGVS & $80-1500$ & 329 & $80-1500$ & 353 & $100-780$ & 285 & $130-1240$ & 348 \\
\hline $\mathrm{SO} 4(\mathrm{mg} / \mathrm{L})$ & $<250$ & $13-3480$ & 456 & $18-1560$ & 201 & $13-2520$ & 389 & $44-3480$ & 779 \\
\hline NO3 $(\mathrm{mg} / \mathrm{L})$ & $<12$ & $0.01-20.4$ & 1.8 & $0.6-20.4$ & 2.4 & $0.1-8.9$ & 1.4 & $0.01-19.5$ & 1.8 \\
\hline TDS (mg/L) & $<1000$ & $177-10773$ & 1368 & $231-4928$ & 845 & $177-4499$ & 980 & $222-10773$ & 2280 \\
\hline $\mathrm{Ca}(\mathrm{mg} / \mathrm{L})$ & $<75$ & 08-1080 & 125 & $08-136$ & 48 & $20-500$ & 114 & $16-1080$ & 213 \\
\hline $\mathrm{Mg}(\mathrm{mg} / \mathrm{L})$ & $<150$ & $4.8-510$ & 73 & $9.7-318$ & 45 & $12-303$ & 59 & $4.9-510$ & 115 \\
\hline $\mathrm{Na}(\mathrm{mg} / \mathrm{L})$ & $<200$ & $12-2840$ & 259 & $14-1050$ & 186 & $12-900$ & 145 & $25-2840$ & 446 \\
\hline $\mathrm{K}(\mathrm{mg} / \mathrm{L})$ & $<12$ & $03-70$ & 13 & $03-70$ & 16 & $03-43$ & 10 & $04-65$ & 14 \\
\hline $\mathrm{Fe}(\mathrm{mg} / \mathrm{L})$ & $<0.3$ & $0.1-1.5$ & 0.4 & $0.1-1.5$ & 0.4 & $0.1-1$ & 0.4 & $0.2-0.5$ & 0.2 \\
\hline $\mathrm{F}(\mathrm{mg} / \mathrm{L})$ & $<1.5$ & $0.01-10$ & 1.1 & $0.01-4.5$ & 1.1 & $0.1-10$ & 1.0 & $0.32-6.5$ & 1.3 \\
\hline As $(\mu \mathrm{g} / \mathrm{L})$ & $<10$ & $5-100$ & 19.3 & $5-100$ & 23.6 & $5-100$ & 18.6 & $5-45$ & 15.8 \\
\hline $\begin{array}{l}\text { Coliform/CFU } \\
\text { Faecal }\end{array}$ & Absent & $0-71$ & 18 & $0-45$ & 15 & $0-71$ & 22 & $0-63$ & 18 \\
\hline Coliform/CFU & Absent & $0-48$ & 16 & $0-43$ & 12 & $0-48$ & 19 & $0-46$ & 17 \\
\hline
\end{tabular}

$\mathrm{GV}=$ guideline values, $\mathrm{NGVS}=$ no guideline value set, $\mathrm{CFU}=$ colony forming unit 
samples have high levels of $\mathrm{Ca}, \mathrm{Mg}$ and hardness as compared to WHO guideline values (WHO 2004). It has been shown that laxative effect may appear due to consumption of drinking water having high concentration of both, $\mathrm{Mg}$ and $\mathrm{SO}_{4}$ (WHO 2010).

Chlorides are present naturally in water, higher content may impart saline taste in drinking water along with creating problems in throat and digestive system (Khan et al. 2000). Analysis data revealed that $15 \%$ water samples have $\mathrm{Cl}$ content higher than WHO permissible limits (Fig. 2). Alkalinity, an important parameter of water quality affects a number of chemical and biological reactions in a human body. Alkalinity varied from 80 to $1500 \mathrm{mg} / \mathrm{L}$, higher concentration may have adverse problems like gas trouble, kidney stones, hardness and damage of metallic pipes (Kudryavtseva 1999). Sodium is also an important mineral element but intake of water with elevated concentration may increase blood pressure. A study conducted on $4^{\text {th }}$ and $5^{\text {th }}$ grade school children revealed that drinking of water with high $\mathrm{Na}$ concentrations have led to an increase in mean arterial and systolic blood pressure (Pomeranz et al. 2002). Present analysis data indicate that 31, 37 and $39 \%$ water samples have high concentration of $\mathrm{Na}, \mathrm{K}$ and $\mathrm{SO}_{4}{ }^{-}$respectively (Fig. 2). A number of waterborne diseases like diarrhoea, respiratory illness, gastrointestinal disorder, weight abatement and dehydration are linked with elevated concentration of $\mathrm{SO}_{4}$ in drinking water (Mazloomi et al. 2009). TDS is a measure of total ion concentration and contribute towards taste, corrosion properties, tendency to incrustation and hardness. Present study indicates that TDS value of $35 \%$ water samples exceed guideline value. Various natural and anthropogenic origins are considered as the main sources of water contamination including industrial, municipal and domestic disposal system, agricultural runoff containing organic and inorganic fertilizers and pesticides (Ritter et al. 2002).

Fluoride is an important micronutrient but higher concentration may contribute towards dental and skeletal fluorosis and other body joints problems (Iqbal et al. 2000). Presented study shows that $15 \%$ water samples have F content higher than recommended value of $1.5 \mathrm{mg} / \mathrm{L}$. It was estimated that consumption of drinking water with $\mathrm{F}$ concentrations $\geq 4.32 \mathrm{ppm}$ for the long term may increase the risk of bone along with hip fractures (Li et al. 2001). Arsenic is a trace element whose high concentration for long term may cause problems like mental retardation, epilepsy, severe hearing loss and other brain damage (Spencer 2000). A number of studies about source, distribution and human health implications of arsenic in different parts of the world have been carried out (McArthur et al. 2001, Smedley et al. 2002, Ayotte et al. 2003, Camacho et al. 2011). Our results show that $87(58 \%)$ water samples have high level of As in comparison to guideline value (10 ppb) as shown in Fig. 3. It has been reported that lungs, skin, kidneys, intestine and liver are among the major body organs affected by high concentration of As due to its involvement in As absorption, accumulation and excretion (Ötleş et al. 2010).

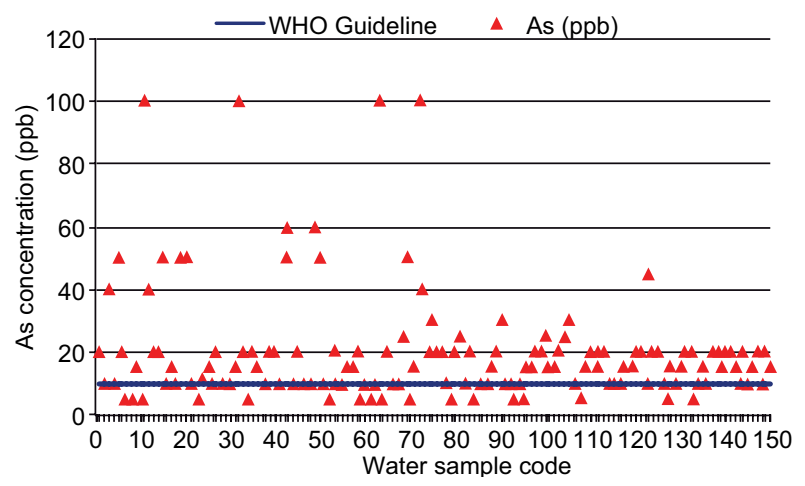

Fig. 3. Illustration of As content in comparison to WHO GV

Research showed that term low birth weight in newborns is associated with chronic exposure to Fe through drinking water (Grazuleviciene et al. 2009). Present study indicates high level of Fe contamination in ground water of southern Punjab as $60 \%$ water samples showed iron content higher than guideline value as shown in Fig. 4. Due to the interaction of water with biosphere and geosphere as a result of hydrological cycle, the ground and surface water sources are generally liable to contain natural organic matter (NOM) to some extent, but during

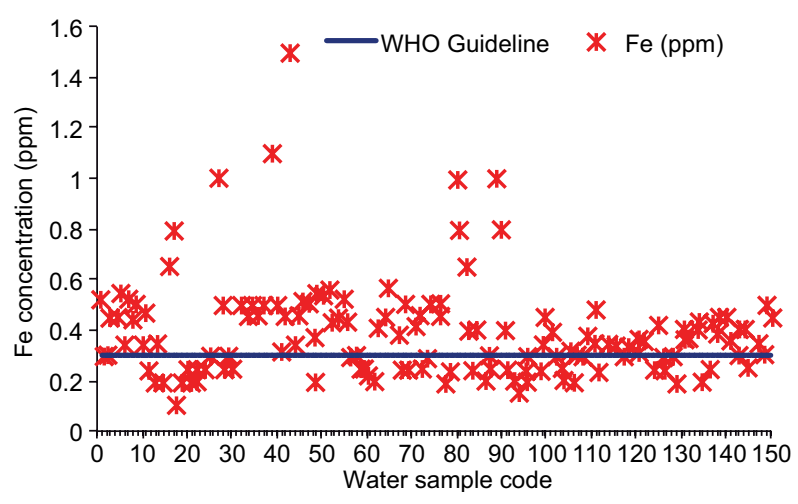

Fig. 4. Illustration of Fe content in comparison to WHO GV 
rains and floods amount of NOM increases much more, which is considered to inhibit oxidation of iron as it is reduced from $\mathrm{Fe}^{+3}$ to $\mathrm{Fe}^{+2}$, and resultantly $\mathrm{Fe}$ concentration is increases in water. Literature showed that the anthropogenic and geogenic activities are responsible for masking Fe concentration in underground water system as is evident from relatively higher concentration of $\mathrm{Fe}$ in some water samples collected from tube wells located near municipal waste waters (Achary 2014).

CDI and HRI were calculated, for children as well as adults, on the basis of concentration of trace elements in drinking water (Table II and III). Calculated CDI values for As ranged from 0.153 to 3.058 and 0.139 to $2.778 \mu \mathrm{g} / \mathrm{kg} /$ day and for Fe from 0.003 to 0.046 and 0.003 to $0.042 \mu \mathrm{g} / \mathrm{kg} /$ day for children and adults respectively. Mean CDI values of As and Fe were higher for water samples collected from Muzaffargarh district as compared to DG Khan and
Rajanpur for both, adults and children as highlighted in table II.

Calculated HRI values were high for As, ranging from 0.510 to 10.194 (mean HRI = 1.972) for children and from 0.463 to 9.259 (mean HRI $=1.791$ ) for adults. Overall HRI was $>1$ in $88 \%$ water samples for children and $58 \%$ for adults. Mean HRI of water samples collected from Muzaffargarh district was higher than those collected from other two districts as shown in table II. HRI for Fe ranged from 4.37E-06 to $6.55 \mathrm{E}-05$ and $3.97 \mathrm{E}-06$ to $5.95 \mathrm{E}-05$ for children and adults respectively indicating overall $\mathrm{HRI}<1$ for $\mathrm{Fe}$. As in ground water of public schools of Southern Punjab is higher than $\mathrm{Fe}$ as shown by HRI calculations. Literature highlights correlation of As with $\mathrm{Fe}$ and other heavy metals and high carcinogenic and non-carcinogenic health risk associated with elevated concentration of As in drinking water (Van Halem et al. 2010). Sultana et al. (2014) investigated water

TABLE II. COMPARISON OF CALCULATED CHRONIC DAILY INTAKE (CDI) RANGE AND MEAN VALUES

\begin{tabular}{llccccc}
\hline \multirow{2}{*}{ District } & & \multicolumn{2}{c}{ As CDI } & \multicolumn{2}{c}{ Fe CDI } \\
\cline { 3 - 4 } \cline { 6 - 6 } & & Children & Adults & & Children & Adults \\
\hline Overall & Range & $0.53-3.058$ & $0.139-2.778$ & & $0.003-0.046$ & $0.003-0.042$ \\
$\mathrm{n}=150$ & Mean & 0.592 & 0.537 & 0.012 & 0.011 \\
\hline Muzafargarh & Range & $0.153-3.058$ & $0.139-2.778$ & $0.003-0.046$ & $0.003-0.042$ \\
$\mathrm{n}=50$ & Mean & 0.723 & 0.657 & 0.013 & 0.012 \\
\hline $\begin{array}{l}\text { Dera Ghazi Khan } \\
\mathrm{n}=50\end{array}$ & Range & $0.153-3.058$ & $0.139-2.778$ & $0.005-0.031$ & $0.004-0.028$ \\
\hline Rajanpur & Mean & 0.569 & 0.517 & 0.012 & 0.011 \\
$\mathrm{n}=50$ & Range & $0.153-1.376$ & $0.139-1.250$ & $0.006-0.015$ & $0.006-0.014$ \\
& Mean & 0.483 & 0.439 & 0.010 & 0.009 \\
\hline
\end{tabular}

TABLE III. COMPARISON OF CALCULATED HEALTH RISK INDEX (HRI) RANGE AND MEAN VALUES

\begin{tabular}{|c|c|c|c|c|c|}
\hline \multirow{2}{*}{ District } & & \multicolumn{2}{|c|}{ As HRI } & \multicolumn{2}{|c|}{ Fe HRI } \\
\hline & & Children & Adults & Children & Adults \\
\hline \multirow{2}{*}{$\begin{array}{l}\text { Overall } \\
\mathrm{n}=150\end{array}$} & Range & $0.510-10.194$ & $0.463-9.259$ & $4.37 \mathrm{E}-06$ to $6.55 \mathrm{E}-05$ & $3.97 \mathrm{E}-06$ to $5.95 \mathrm{E}-05$ \\
\hline & Mean & 1.972 & 1.791 & $1.70 \mathrm{E}-05$ & $1.55 \mathrm{E}-05$ \\
\hline \multirow{2}{*}{$\begin{array}{l}\text { Muzafargarh } \\
\mathrm{n}=50\end{array}$} & Range & $0.510-10.194$ & $0.463-9.259$ & $4.37 \mathrm{E}-06$ to $6.55 \mathrm{E}-05$ & $3.97 \mathrm{E}-06$ to $5.95 \mathrm{E}-05$ \\
\hline & Mean & 2.410 & 2.189 & $1.91 \mathrm{E}-05$ & $1.73 \mathrm{E}-05$ \\
\hline \multirow{2}{*}{$\begin{array}{l}\text { Dera Ghazi Khan } \\
n=50\end{array}$} & Range & $0.510-10.194$ & $0.463-9.259$ & $6.55 \mathrm{E}-06$ to $4.37 \mathrm{E}-05$ & $5.95 \mathrm{E}-06$ to $3.97 \mathrm{E}-05$ \\
\hline & Mean & 1.896 & 1.722 & $1.73 \mathrm{E}-05$ & $1.57 \mathrm{E}-05$ \\
\hline \multirow{2}{*}{$\begin{array}{l}\text { Rajanpur } \\
\mathrm{n}=50\end{array}$} & Range & $0.510-4.578$ & $0.463-4.167$ & $8.74 \mathrm{E}-06$ to $2.18 \mathrm{E}-05$ & $7.94 \mathrm{E}-06$ to $1.98 \mathrm{E}-05$ \\
\hline & Mean & 1.611 & 1.463 & $1.48 \mathrm{E}-05$ & $1.34 \mathrm{E}-05$ \\
\hline
\end{tabular}


quality of Lahore, Punjab and concluded that $87 \%$ water samples have HQ values greater than 1.00 (HQ = 2.3-48.6) (Sultana et al. 2014).

In order to reduce bacterial contamination, it is suggested that disinfection campaign should be launched among the residents for mitigation of microbiological risks. Boiling of drinking water is considered as the most effective means of water disinfection, which destroys all the coliform bacteria. Alternatively, use of solar rays could be considered as a cheaper method but it does not eliminate microbial load completely. However, granular activated carbon filtration is the most suitable technique for decreasing microbial content of the drinking water. Concerned authorities should launch public awareness scheme about waterborne diseases and undertake the initiative to encourage the culture of hygiene and sanitation among people of the area.

Keeping in view the physical and-chemical results of water samples analyzed, it is recommended that any treatment process should be implemented so that high concentration of $\mathrm{Na}, \mathrm{K}, \mathrm{SO}_{4}, \mathrm{~F}, \mathrm{Fe}$ and As may be reduced. It is also recommended that use of available household water treatment techniques for $\mathrm{As}$ and $\mathrm{Fe}$ should be encouraged among the inhabitants. A more comprehensive study should be carried out in the region to identify and designate safe drinking water sources in near about areas of public schools so that students may have access to safe drinking water. Moreover, periodical water quality analysis of pre-identified and designated water sources is very important.

\section{CONCLUSION}

Water quality assessment of public schools in flood affected area of Southern Punjab revealed that most of water samples were highly contaminated with total coliform (49\%), faecal coliform (37\%), Fe (60 $\%)$, As (58 \%), $\mathrm{SO}_{4}(39 \%)$ and TDS (35\%) posing serious threat to healthy lives of youngsters, which may contribute toward a severe health dilemma. In addition, a number of sampling sites were contaminated with other chemicals constituents like $\mathrm{Ca}, \mathrm{Mg}$, $\mathrm{F}, \mathrm{Na}, \mathrm{K}$ and $\mathrm{Cl}$ as well. It is concluded that drinking water quality in public schools is substandard, as is evident from high level of microbial contamination and other chemicals constituents. It is recommended to devise a concrete policy for purification of drinking water and addressing post-flood environmental effects so that safety from harmful effects of bacterial contamination and other toxic pollutants may be ensured.

\section{ACKNOWLEDGMENTS}

Authors acknowledge the efforts of Pakistan Council of Research in Water Resources (PCRWR) and laboratory Sargodha staff for cooperation in laboratory analysis.

\section{REFERENCES}

Achary G.S. (2014). Studies on ground water pollution due to iron content in Cuttack city, Odisha, India. Int. J. Multidiscip. Curr. Res. 2, 86-89.

Adepoju-Bello A. and Alabi O. (2005). Heavy metals: A review. The Niger. J. Pharm. 37, 41-45.

Akhter G., Ahmad Z., Iqbal J., Shaheen N. and Shah M.H. (2010). Physicochemical characterization of groundwater in urban areas of Lahore, Pakistan, with special reference to arsenic. J. Chem. Soc. Pak. 32 (3), 306-312.

Alamgir A., Khan M.A., Schilling J., Shaukat S.S. and S. Shahab. (2016). Assessment of groundwater quality in the coastal area of Sindh province, Pakistan. Environ. Monit. Assess. 188 (2), 1-13.

DOI: $10.1007 / \mathrm{s} 10661-015-5061-\mathrm{x}$

Ashbolt N.J. (2004). Microbial contamination of drinking water and disease outcomes in developing regions. Toxicology 198 (1-3), 229-238.

DOI: $10.1016 / j . t o x .2004 .01 .030$

Ayotte J.D., Montgomery D.L., Flanagan S.M. and Robinson K.W. (2003). Arsenic in groundwater in eastern New England: occurrence, controls, and human health implications. Environ. Sci. Technol. 37 (10), 2075-2083.

DOI: $10.1021 / \mathrm{es} 026211 \mathrm{~g}$

Baig S., Xu X. and R. Khan. (2012). Microbial water quality risks to public health: potable water assessment for a flood-affected town in northern Pakistan. Rural Remote Health 12 (3), 2196

Camacho L.M., Gutiérrez M., Alarcón-Herrera M.T., de Lourdes Villalba M. and Deng S. (2011). Occurrence and treatment of arsenic in groundwater and soil in northern Mexico and Southwestern USA. Chemosphere 83 (3), 211-225.

DOI: $10.1016 /$ j.chemosphere.2010.12.067

Clesceri L.S., Greenberg A.E and Eaton A.D. (2005). Standard methods for the examination of water and wastewater, Americam Public Health Association (APHA) and Water Environment Federation. 21, 258-259.

Grazuleviciene R., Nadisauskiene R., Buinauskiene J. and T. Grazulevicius. (2009). Effects of elevated levels of manganese and iron in drinking water on birth outcomes.Stress 18 (5), 11. 
Imitiaz N., Aftab T., Iqbal Z., Asi M. and Hussain A. (2004). Nitrate burden in drinking water in Northern Punjab, Pakistan: A challenge for public health. J. Chem. Soc. Pak. 26 (4), 450-452.

Iqbal Y., Alam S., Sabir S., Ishaq M. and Ahmad N. (2000). Investigation of pollutants in the industrial effluents. J. Chem. Soc. Pak. 22 (4), 239-244

Khan A., Haq I., Khan W., Akif M., Khan M. and Riaz M. (2000). Quality characteristics of Potable water of Mardan city (Pakistan) and surrounding areas. J. Chem. Soc. Pak. 22 (2), 87-93.

Khan A., Hussain F., Khan M. and Riaz M. (1999). Quality characteristics of potable water from different sources of district Bannu (Pakistan) and their possible health impacts. J. Chem. Soc. Pak. 21 (2), 106-114.

Khan S., Rehman S., Khan A.Z., Khan M.A. and Shah M.T. (2010). Soil and vegetables enrichment with heavy metals from geological sources in Gilgit, northern Pakistan. Ecotoxicol. Environ. Saf. 73 (7), 1820-1827. DOI: 10.1016/j.ecoenv.2010.08.016

Khan S.U. and Bangash F.K. (2001). Drinking water quality forecast of Peshawar valley on the basis of sample data. J. Chem. Soc. Pak. 23 (3), 243-251.

Kudryavtseva L.P. (1999). Assessment of drinking water quality in the city of Apatit. Water Res. 26 (6), 659-665.

Laluraj C. and Gopinath G. (2006). Assessment on seasonal variation of groundwater quality of phreatic aquifers-a river basin system. Environ. Monit. Assess. 117 (1-3), 45-57. DOI: 10.1007/s10661-006-7675-5

Li Y., Liang C., Slemenda C.W., Ji R., Sun S., Cao J., Emsley C.L., Ma F., Wu Y. and Ying P. (2001). Effect of long-term exposure to fluoride in drinking water on risks of bone fractures. J. Bone Miner. Res. 16 (5), 932-939. 10.1359/jbmr.2001.16.5.932

Malik M.A., Azam E.M. and Saboor A. (2010). Water quality status of upper KPK and northern areas of Pakistan, Water Resources Research Center, Peshawar, Ministry of Science and Technology, Peshawar, Report No. 142.

Mazloomi S., Dehghani M.H., Norouzi M., Fazlzadeh Davil M., Amarluie A. and Tardast A. (2009). Physical and chemical water quality of ilam water treatment plant. World Appl. Sci. J. 6 (12), 1660-1664.

McArthur J.M., Ravenscroft P., Safiulla S. and Thirlwall M.F. (2001). Arsenic in groundwater: testing pollution mechanisms for sedimentary aquifers in Bangladesh. Water Resour. Res. 37 (1), 109-117. DOI: 10.1029/2000wr900270

Memon M., Soomro M.S., Akhtar M.S. and Memon K.S. (2011). Drinking water quality assessment in Southern Sindh (Pakistan). Environ. Monit. Assess. 177 (1-4), 39-50. DOI: 10.1007/s10661-010-1616-Z

Mohamed W.S., Alsulaimani A.A., Serwah A.H.A., Ginawi I.A. and Kosba A.A. (2015). The relationship between different kinds of drinking water in Saudi Arabia with the incidence of renal diseases. Int. Res. J. Med. Med. Sci. 3 (4), 94-102.

Mohsin M., Safdar S., Asghar F. and Jamal F. (2013). Assessment of drinking water quality and its impact on residents health in Bahawalpur city. Intl. J. Human. Soc.Sci. 3 (15), 114-128.

Muhammad F., Ikram M., Khan S., Khan K., Shah S.H., Badshah Z., Ahmad W. and Shah S.N. (2013). Flood disaster in Charasadda, Pakistan: bacteriological examination of drinking water. Intl. J. Biosci. 3 (5), 51-59. DOI: 10.12692/ijb/3.5.51-59

Muhammad S., Shah M.T. and Khan S. (2010). Arsenic health risk assessment in drinking water and source apportionment using multivariate statistical techniques in Kohistan region, Northern Pakistan. Food Chem. Toxicol. 48 (10), 2855-2864.

DOI: $10.1016 /$ j.fct.2010.07.018

Nabeela F., Azizullah A., Bibi R., Uzma S., Murad W., Shakir S.K., Ullah W., Qasim M. and Häder D.P. (2014). Microbial contamination of drinking water in Pakistan-a review. Environ. Sci. Pollut. Res. 21 (24), 13929-13942.

Nickson R., McArthur L., Shrestha B., Kyaw-Myint T. and Lowry D. (2005). Arsenic and other drinking water quality issues, Muzaffargarh District, Pakistan. Appl. Geochem. 20 (1), 55-68.

DOI: 10.1016/j.apgeochem.2004.06.004

Ötleş S. and Çağındı O. (2010). Health importance of arsenic in drinking water and food. Environ. Geochem. Health 32 (4), 367-371. DOI: $10.1007 / \mathrm{s} 10653-010-9296-8$

Phiri O., Mumba P., Moyo B. and Kadewa W. (2005). Assessment of the impact of industrial effluents on water quality of receiving rivers in urban areas of Malawi. Int. J. Environ. Sci. Technol. 2 (3), 237-244. DOI: $10.1007 / \mathrm{bf03325882}$

Pomeranz A., Dolfin T., Korzets Z. E., Eliakim A. and Wolach B. (2002). Increased sodium concentrations in drinking water increase blood pressure in neonates. J. Hypertens. 20 (2), 203-207. DOI: 10.1097/00004872-200202000-00009

Qadeer R. (2004). Pollutants in drinking water: Their sources, harmful effects and removal procedures. J. Chem. Soc. Pak. 26 (3), 293-327

Rasool A., Farooqi A., Masood S. and Hussain K. (2016). Arsenic in groundwater and its health risk assessment in drinking water of Mailsi, Punjab, Pakistan. Human and Ecological Risk Assess. Intl. J. 22 (1), 187-202. DOI: $10.1080 / 10807039.2015 .1056295$

Rice E.W., Baird R.B., Eaton A.D. and Clesceri L.S. (2012). Standard methods for the examination of water and wastewater. 22nd Edition, American Public Health 
Association, American Water Works Association and Water Environment Federation, Washington, D. C., USA, 1496 pp.

Ritter L., Solomon K., Sibley P., Hall K., Keen P., Mattu G. and Linton B. (2002). Sources, pathways, and relative risks of contaminants in surface water and groundwater: a perspective prepared for the Walkerton inquiry. J. Toxicol. Environ. Health Part A 65 (1), 1-142. DOI: $10.1080 / 152873902753338572$

Sarfraz M., Sultana N. and Jamil M. (2018). Groundwater quality and health risk assessment in rural areas of district Jaffarabad, Baluchistan (Pakistan). Pak. J. Anal. Environ. Chem. 19 (1), 129-135.

DOI: $10.21743 / \mathrm{pjaec} / 2018.06 .08$

Sarfraz M., Sultana N. and Tariq M.I. (2018). Assessment of groundwater quality and associated health risks in rural areas of Sindh (Pakistan). Studia Chemia 63 (1), 125-136.

DOI: $10.24193 /$ subbchem.2018.1.10

Sarfraz M., Sultana N., Jamil M. and Ashraf R. (2016). Investigation of portable groundwater quality and health risk assessment of selected trace metals in flood affected areas of district Rajanpur, Pakistan. J. Environ. Anal. Chem. 3, 183.

DOI: $10.4172 / 2380-2391.1000183$

Sengupta P. (2013). Potential health impacts of hard water. Intl. J. Preven. Med. 4(8), 866

Shah M., Ara J., Muhammad S., Khan S. and Tariq S. (2012). Health risk assessment via surface water and sub-surface water consumption in the mafic and ultramafic terrain, Mohmand agency, Northern Pakistan. J. Geochem. Explor. 118, 60-67. DOI: 10.1016/j.gexplo.2012.04.008

Shakoor M.B., Niazi N.K., Bibi I., Rahman M.M., Naidu R., Dong Z., Shahid M. and Arshad M. (2015). Unraveling health risk and speciation of arsenic from groundwater in rural areas of Punjab, Pakistan. Int. J. Environ. Res. Public Health 12 (10), 12371-12390. DOI: 10.3390/ijerph121012371
Smedley P.L. and Kinniburgh D.G. (2002). A review of the source, behaviour and distribution of arsenic in natural waters. Appl. Geochem. 17 (5), 517-568.

DOI: 10.1016/s0883-2927(02)00018-5

Spencer J.E. (2000). Arsenic in ground water. Arizona geology: Arizona Geological Survey 30, 1-4.

Sultana J., Farooqi A. and Ali U. (2014). Arsenic concentration variability, health risk assessment, and source identification using multivariate analysis in selected villages of public water system, Lahore, Pakistan. Environ. Monit.Assess. 186 (2), 1241-1251.

DOI: $10.1007 / \mathrm{s} 10661-013-3453-3$

Van Halem D., Olivero S., de Vet W., Verberk J., Amy G. and van Dijk J. (2010). Subsurface iron and arsenic removal for shallow tube well drinking water supply in rural Bangladesh. Water Res. 44 (19), 5761-5769. DOI: 10.1016/j.watres.2010.05.049

Venkatramanan S., Chung S., Kim T., Prasanna M. and Hamm S. (2015). Assessment and distribution of metals contamination in groundwater: a case study of Busan City, Korea. Water Qual., Exposure Health 7 (2), 219-225. DOI: $10.1007 / \mathrm{s} 12403-014-0142-6$

Wakida F.T. and Lerner D.N. (2005). Non-agricultural sources of groundwater nitrate: a review and case study. Water Res. 39 (1), 3-16.

DOI: $10.1016 /$ j.watres.2004.07.026

WHO (1963). International standards for drinking-water. 2nd Edition, World Health Organization, Geneva. Switzerland, 204.

WHO (2000). Global water supply and sanitation assessment 2000 report, World Health Organization / United Nations International Children's Emergency Fund joint monitoring programme for water supply and sanitation. Geneva, Switzerland.

WHO (2004). Guidelines for drinking-water quality: recommendations. 3rd Edition, Vol. 1, World Health Organization, Geneva, Switzerland, 494 pp.

WHO (2010). World health statistics 2010. World Health Organization. Geneva, Switzerland, 168 pp. 